Čelebić A, Stančić I, Kovačić I, Popovac A, Topić J, Mehulić K, Elenčevski S, Peršić S. Psychometric characteristics of the Croatian and the Serbian versions of the oral health impact profile for edentulous subjects, with a pilot study on the dimensionality. Zdr Varst. 2021;60(1):55-64. doi: 10.2478/sjph-2021-0009.

\title{
PSYCHOMETRIC CHARACTERISTICS OF THE CROATIAN AND THE SERBIAN VERSIONS OF THE ORAL HEALTH IMPACT PROFILE FOR EDENTULOUS SUBJECTS, WITH A PILOT STUDY ON THE DIMENSIONALITY PSIHOMETRIČNE LASTNOSTI HRVAŠKE IN SRBSKE RAZLIČICE VPRAŠALNIKA ZA OCENO KAKOVOSTI ŽIVLJENJA V POVEZAVI Z ORALNIM ZDRAVJEM (OHRQOL) ZA BREZZOBO POPULACIJO
}

\author{
Asja ČELEBIĆ ${ }^{*}$, Ivica STANČIĆ2 ${ }^{2}$ Ines KOVAČIĆ ${ }^{1}$, Aleksandra POPOVAC², \\ Jolanda TOPIĆ ${ }^{3}$, Ketij MEHULIĆ 1 , Sašo ELENČEVSKI ${ }^{4}$, Sanja PERŠIĆ ${ }^{1}$
}

\author{
'University of Zagreb, School of Dental Medicine, Department of Removable Prosthodontics, \\ Gunduličeva 5, 10000 Zagreb, Croatia \\ 2University of Beograd, School of Dentistry, Department of Prosthodontics, Serbia \\ ${ }^{3}$ Private Dental Office, Makarska, Croatia \\ ${ }^{4}$ University of Skopje, Faculty of Dentistry, Department of Prosthodontics, North Macedonia
}

\section{IZVLEČEK}

Ključne besede: OHIP-EDENT, vprašalnik, prilagoditev, zanesljivost, veljavnost, odzivnost, EFA, Hrvaška, Srbija

\begin{abstract}
Keywords: OHIP-EDENT, questionnaire, adaptation, reliability, validity, responsiveness, EFA, Croatia, Serbia

Introduction: The aim was to adapt the Croatian and the Serbian versions of the Oral Health Impact Profile for the edentulous population (OHIP-EDENT-CRO and OHIP-EDENT-SRB).

Methods: The translation and cross-cultural adaptation were carried out in accordance with accepted international standards. A total of 95 and 177 removable denture wearers were recruited in Croatia and Serbia respectively. The reliability was evaluated by calculating Cronbach's alpha coefficient and by test-retest ( 30 participants in each country). The concurrent validity was determined by calculating the Spearman's rank coefficient between the OHIP-EDENT summary scores and one question related to removable denture satisfaction. Construct validity was determined by exploratory factor analysis (EFA). Responsiveness was determined by comparison of the OHIP-EDENT summary scores before and after dental implant placement to support mandibular overdentures (23 patients in Croatia, 21 in Serbia).
\end{abstract}

Results: Cronbach's alpha coefficient was 0.92 in Croatia and 0.87 in Serbia. The intraclass correlation coefficient was 0.98 in Croatia and 0.94 in Serbia. In Croatia the Spearman's correlation coefficient was $-0.71(p<0.001)$ and in Serbia $-0.74(\mathrm{p}<0.001)$. Both confirmed concurrent validity. Construct validity was tested by EFA, which extracted four factors in each country, accounting for $66.59 \%$ of the variance in Croatia and $59.33 \%$ in Serbia. Responsiveness was confirmed in both countries by a significant OHIP-EDENT summary score reduction and a high standardised effect size (3.9 in Croatia, 1.53 in Serbia).

Conclusion: The results prove that both instruments, the OHIP-EDENT-CRO and the OHIP-EDENT-SRB, have very good psychometric properties for assessing OHRQoL in the edentulous population.

Uvod: Namen raziskave je določiti psihometrične lastnosti hrvaške in srbske različice vprašalnika za oceno kakovosti življenja v zvezi z oralnim zdravjem (OHRQoL), to je »Oral Health Impact Profile za brezzobo populacijo (OHIP-EDENT-CRO in OHIP-EDENT-SRB).

Metode: Prevod in medkulturno prilagajanje sta bila izvedena $v$ skladu s sprejetimi mednarodnimi standardi. Na Hrvaškem in v Srbiji je bilo vključenih 95 oziroma 177 udeležencev s snemno zobno protezo. Zanesljivost smo ocenili z izračunom Cronbachovega koeficienta alfa in s ponovnim testom, ki je vključeval 30 udeležencev v vsaki državi. Sočasna veljavnost je bila določena z izračunom Spearmanovega koeficienta ranga med zbirnimi ocenami OHIPEDENT in enim vprašanjem $v$ zvezi z zadovoljstvom s snemno protezo. Veljavnost konstrukta je bila določena $z$ eksplorativno faktorsko analizo (EFA). Odzivnost je bila določena s primerjavo zbirnih rezultatov OHIP-EDENT pred namestitvijo zobnega vsadka za podporo mandibularne delne proteze in po njej (23 hrvaških in 21 srbskih pacientov).

Rezultati: Cronbachov koeficient alfa je na Hrvaškem in v Srbiji znašal 0,92 oziroma 0,87. Intraklasni korelacijski koeficient je znašal 0,98 za hrvaško in 0,94 za srbsko različico. Za hrvaško različico je Spearmanov koeficient korelacije znašal -0,71 ( $p<0,001)$, za srbsko pa -0,74 ( $p<0,001)$ in pri obeh je bila potrjena sočasna veljavnost. Veljavnost konstrukta je bila preizkušena z EFA, ki je $v$ vsaki jezikovni različici določila štiri dejavnike. Ti pojasnjujejo 66,59 \% variance pri hrvaškem in 59,33 \% variance pri srbskem vprašalniku. Odzivnost je bila v obeh državah potrjena z znatnim zmanjšanjem skupnega rezultata OHIP-EDENT in z visoko vrednostjo standardizirane velikosti učinka (3,9 na Hrvaškem; 1,53 v Srbiji).

Zaključek: Rezultati dokazujejo, da imata oba instrumenta, OHIP-EDENT-CRO in OHIP-EDENT-SRB, zelo dobre psihometrične lastnosti za oceno OHRQoL pri brezzobi populaciji. 


\section{INTRODUCTION}

Oral health-related quality of life (OHRQoL), as a part of general health and well-being, has become very important in dental epidemiological and clinical studies that measure the extent of teeth loss and the impact of dental intervention (1-4). A recent study identified 20 Dental Patient-Reported Outcome Measure (dPROM) Questionnaires with multiple items in the English language (5). Some of them were aimed at a specific population, such as the young (6), elderly (7), disease-specific $(8,9)$ or edentulous population (10). Unidimensional questionnaires were developed to measure one specific dimension of OHRQoL, such as the Orofacial Esthetic Scale (11) or the Chewing Function Questionnaire (12). However, the Oral Health Impact Profile (OHIP), a multidimensional questionnaire, has been one of the most frequently used dPROMs. The original version, with 49 items grouped into seven theoretical domains (functional limitation, physical pain, physical limitation, psychological discomfort, social limitation, and disability (handicap)), has been translated into more than 30 languages and culturally adapted (13). Recent studies reported the existence of only four major dimensions for the OHIP-49 questionnaire, i.e., Oral Function, Orofacial Pain, Orofacial Appearance and Psychosocial Impact (14-16). The short 14-item OHIP questionnaire was developed soon after the original one (17) and adapted worldwide to reduce the time required and the number of incomplete answers. Owing to the floor effect, it was not sensitive enough for status measurement and treatment improvements in edentulous subjects (10). The 19-item OHIP-EDENT questionnaire has therefore been developed and adapted in several different cultural environments $(10,18-20)$.

The OHIP-49 and the OHIP-14 questionnaires have already been validated in Slovenia, while in Serbia only the OHIP14 has been validated (21-23). The OHIP-EDENT has not yet been translated or psychometrically validated either in Croatia or Serbia. The aim was to develop Croatian and Serbian versions of the OHIP-EDENT, validate them in a target population, and perform a pilot study of the dimensionality of the questionnaires. The hypothesis was that both versions would show good reliability, validity and responsiveness.

\section{MATERIAL AND METHODS}

\subsection{Participants}

A sample of 95 participants was recruited at the School of Dental Medicine, University of Zagreb, Croatia. A sample of 177 participants was recruited at the Faculty of Dental Medicine, University of Belgrade, Serbia. The criterion for inclusion was the wearing of maxillary and mandibular removable dentures for at least six months prior to the research. This was to ensure full adaptation. In Croatia, 83 participants had complete dentures (CD) in both jaws, while 12 had one complete and one partial removable denture. In Serbia, all participants were CD wearers. Subjects who reported a history of mental disorders in anamnestic data were excluded. The sample size was determined using a strategy similar to that used in other studies $(19,24)$. A minimum of 95 participants was required. Participants answered questions from the OHIP-EDENT questionnaire by rating the frequency of a particular problem experienced during the previous week (25). The responses were rated on a Likert-type scale $(0$ - never, 1 - hardly ever, 2 - occasionally, 3 - fairly often, 4 - very often), where "zero" represented the absence of problems while higher scores represented more problems and worse oral health. The research has been conducted in accordance with the Declaration of Helsinki. Written informed consents were obtained from each participant. The study was approved by the ethics committees of the Croatian (approval no 05-PA-26-6/2015) and Serbian dental schools (approval no 36/18).

\subsection{Translation}

The OHIP-EDENT was translated using the accepted standard of the forward-backward process (26). The original and back-translated versions were compared by two specialists in prosthodontics with fluency in the English language, together with one native English language speaker in both countries. The preliminary versions were additionally pilot-tested in ten $C D$ wearers to check understanding and clarity of the items. The OHIP-EDENT-CRO and the OHIP-EDENT-SRB questions are shown in Figure 1. 


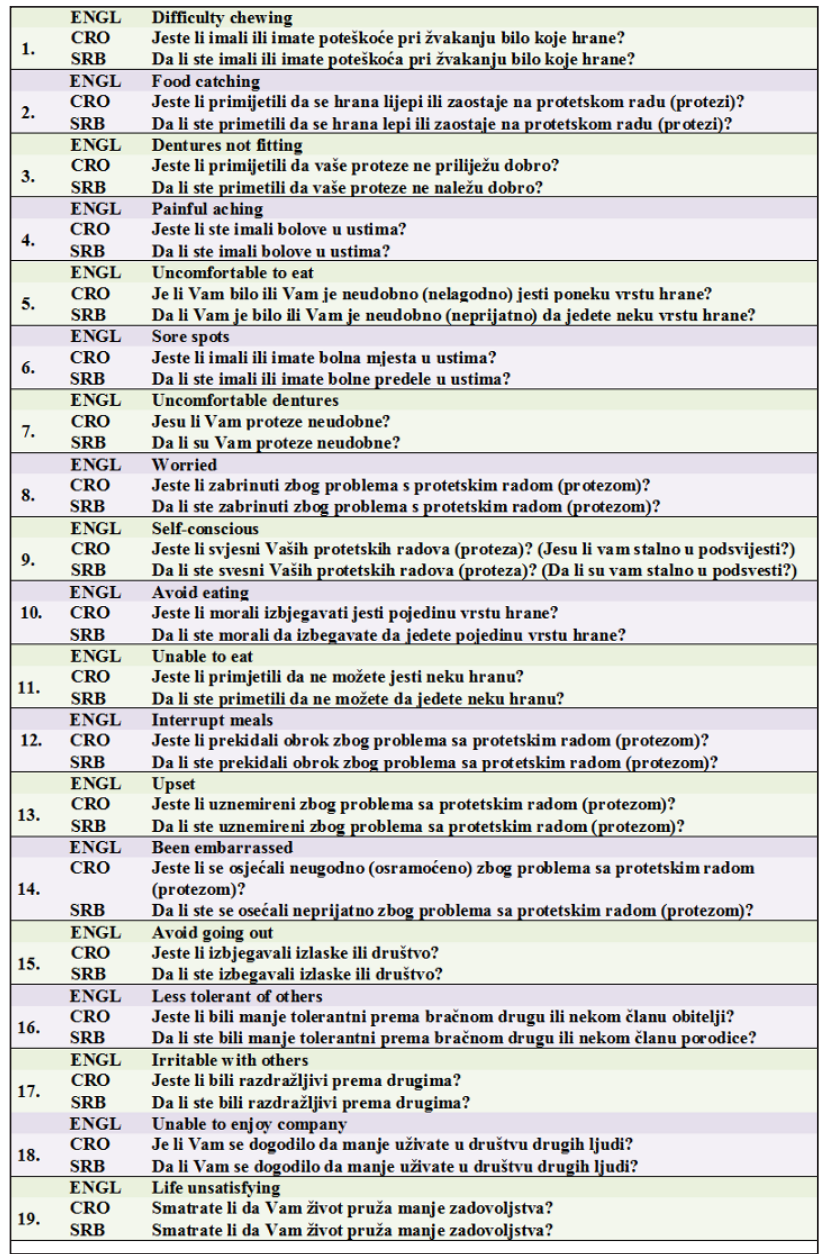

Figure 1. Translation of the original English language OHIPEDENT into the Croatian and Serbian languages.

\subsection{Reliability}

Two types of reliability were assessed: internal consistency and test-retest reliability. The internal consistency was assessed by calculating Cronbach's alpha coefficient, which captures the extent of agreement between all possible subsets of questions. Guttman's "Split-Half" coefficient was also calculated. A value of $>0.7$ was considered acceptable.

The test-retest reliability was assessed in 30 participants willing to make a recall visit in each country. They were not provided with any treatment between the two administrations of the questionnaire. The prediction was that OHRQoL would not change during a 15-day treatmentfree period. The test-retest reliability was assessed by intraclass correlation coefficients (ICC) of the OHIP-EDENT summary scores, based on the one-way repeated-measure analysis of variance (ANOVA) from the repeated tests.

\subsection{Validity}

Concurrent validity assessed the degree to which the OHIPEDENT summary scores correlated with another measure of the same construct at the same time. The association between the OHIP-EDENT summary score and a simple question, "Please rate your satisfaction with dentures", was assessed in both countries. Satisfaction with the existing dentures was rated from 1 to 5 (1 represented the worst and 5 the best score). It was assumed that patients who rated their dentures with higher scores would have lower OHIP-EDENT summary scores. Spearman's correlation coefficient was calculated.

Construct validity was assessed using exploratory factor analysis (EFA) to identify interrelationships and groupings among items in the OHIP-EDENT-CRO and the OHIP-EDENTSRB. Before performing EFA, the Kaiser-Meyer-Olkin (KMO) measure of sampling adequacy and Bartlett's Test of Sphericity were conducted. KMO values above 0.6 and a Bartlett's Test of Sphericity significance of $<0.0001$ were considered adequate for the performance of EFA. The main factors were extracted using the Principal Component Analysis, and varimax rotation was performed. A minimum eigenvalue of 1 was assigned as the factor extraction criterion. Item loadings $\geq 0.4$ were considered sufficient (27).

\subsection{Responsiveness}

Responsiveness is defined as the ability of the measure to evaluate changes after therapy in patients over time (28). We had two samples: 21 CD wearers in Serbia and 23 CD wearers in Croatia. In Serbia, 21 CD wearers received two standard-size implants in the mandible in approximate sites of previous canines. After osseointegration (three months), the implants were loaded. The Locator system was used and the abutments were screwed at $35 \mathrm{Ncm}$. Metal housings were mounted using a self-curing acrylic resin into the existing mandibular dentures, which were relined and adjusted when necessary. A sample of $23 \mathrm{CD}$ wearers was recruited in Croatia. All participants had slim alveolar ridges $(\leq 4 \mathrm{~mm})$ in the mandible. They therefore received four slim ball-type mini dental implants (MDIs) in the interforaminal region. Early loading protocol was used. Metal housings with "o-rings" were attached into the existing mandibular CDs using a self-curing resin. The dentures were relined when necessary. The participants completed the questionnaire twice: before the implant placement and one month after the implants had been loaded and the dentures adjusted. The standardised effect size was calculated using the equation: Mean (baseline OHIP-EDENT score - follow-up OHIP-EDENT)/ Standard deviation of the baseline OHIP-EDENT score (29). 


\section{RESULTS}

\subsection{Participants}

A sample of 95 participants was recruited in Croatia and 177 participants in Serbia. Sampling strategies, together with the participants' age and demographic characteristics, are presented in Table 1.

\subsection{Reliability}

\subsubsection{Internal consistency}

Cronbach's alpha coefficients, average inter-item correlations, mean and summary scores with standard deviations of the OHIP-EDENT questionnaires, as well as Guttman's Split-Half coefficients, are presented in Table 2. In Croatia, higher Cronbach's alpha and Guttman's SplitHalf Coefficients were obtained, as well as higher mean item score and mean summary score (Table 2).

Table 3 presents mean scores of each item with standard deviations, corrected item-total correlation, Cronbach's alpha when one item was deleted, and factor loadings (EFA) of both questionnaires. All item-total correlations were above 0.20 . Even if one item was deleted, Cronbach's alpha coefficient remained higher than 0.7 .

Table 1. Sampling strategy and participants' demographic data.

\begin{tabular}{|c|c|c|c|c|c|c|c|c|}
\hline Country & Sample & Sampling & $\begin{array}{l}\text { Research } \\
\text { purpose }\end{array}$ & $\begin{array}{l}\mathrm{n} \\
\text { (\% women) }\end{array}$ & $\begin{array}{l}\text { Mean age } \\
\text { (years) } \\
M \pm S D\end{array}$ & $\begin{array}{l}\text { Age range } \\
\text { (years) }\end{array}$ & $\begin{array}{l}\text { Duration of } \\
\text { edentulism } \\
(M \pm S D)\end{array}$ & $\begin{array}{l}\text { Range of } \\
\text { edentulism } \\
\text { (years) }\end{array}$ \\
\hline \multirow[t]{3}{*}{ Croatia } & $\begin{array}{l}\text { Removable } \\
\text { denture } \\
\text { wearers }\end{array}$ & Convenience & $\begin{array}{l}\text { Internal } \\
\text { consistency, } \\
\text { Concurrent } \\
\text { validity }\end{array}$ & 95 (65\%) & $69.08 \pm 9.2$ & $51-93$ & $7.6 \pm 7.9$ & $1-30$ \\
\hline & $\begin{array}{l}\text { Removable } \\
\text { denture } \\
\text { wearers }\end{array}$ & Consecutive & $\begin{array}{l}\text { Test-retest } \\
\text { reliability }\end{array}$ & $30(60 \%)$ & $71.8 \pm 10.2$ & $52-91$ & $7.6 \pm 6.6$ & $1-30$ \\
\hline & $\begin{array}{l}\text { Removable } \\
\text { denture } \\
\text { wearers }\end{array}$ & Convenience & Responsiveness & $23(61 \%)$ & $66.6 \pm 10.2$ & $51-93$ & $7.6 \pm 5.9$ & $2-28$ \\
\hline \multirow[t]{3}{*}{ Serbia } & $\begin{array}{l}\text { Complete } \\
\text { denture } \\
\text { wearers }\end{array}$ & Convenience & $\begin{array}{l}\text { Internal } \\
\text { consistency, } \\
\text { Concurrent } \\
\text { validity }\end{array}$ & 90 (51\%) & $63.8 \pm 11.5$ & $35-90$ & $3.5 \pm 7.6$ & $1-21$ \\
\hline & $\begin{array}{l}\text { Complete } \\
\text { denture } \\
\text { wearers }\end{array}$ & Consecutive & $\begin{array}{l}\text { Test-retest } \\
\text { reliability }\end{array}$ & $30(40 \%)$ & $65.3 \pm 10.3$ & $43-90$ & $3.8 \pm 6.6$ & $1-18$ \\
\hline & $\begin{array}{l}\text { Complete } \\
\text { denture } \\
\text { wearers }\end{array}$ & Convenience & Responsiveness & $21(43 \%)$ & $63.8 \pm 10.5$ & $42-79$ & $3.5 \pm 5.6$ & $1-14$ \\
\hline
\end{tabular}

$M=$ mean value; $S D=$ standard deviation

Table 2. Cronbach's alpha coefficient, average inter-item correlation, mean and summary scores with standard deviations, and Guttman's Split-Half Coefficients of the OHIP-EDENT-CRO and the OHIP-EDENT-SRB; n=number of participants.

\begin{tabular}{|c|c|c|c|c|c|c|}
\hline Questionnaire & $\mathrm{n}$ & Cronbach's a & $\begin{array}{l}\text { Average inter- } \\
\text { item correlation }\end{array}$ & $\begin{array}{l}\text { Mean Summary } \\
\text { Score }\end{array}$ & $\begin{array}{l}\text { SD (Mean } \\
\text { Summary Score) }\end{array}$ & $\begin{array}{l}\text { Guttman's Split- } \\
\text { Half Coefficient }\end{array}$ \\
\hline \multicolumn{7}{|l|}{ OHIP-EDENT-CRO } \\
\hline Participants & 95 & 0.92 & 0.39 & 30.21 & 15.95 & 0.83 \\
\hline \multicolumn{7}{|l|}{ OHIP-EDENT-SRB } \\
\hline Participants & 177 & 0.87 & 0.25 & 19.51 & 7.60 & 0.74 \\
\hline
\end{tabular}

$\mathrm{SD}=$ standard deviation 
Table 3. Mean item scores, standard deviations, corrected item-total correlations, Cronbach's alpha coefficients when the item was deleted, and factor loadings of the OHIP-EDENT-CRO and the OHIP-EDENT-SRB; SD=standard deviation.

\begin{tabular}{|c|c|c|c|c|c|c|c|c|c|c|}
\hline \multirow[t]{2}{*}{ Questionnaire } & \multicolumn{5}{|c|}{ OHIP-EDENT-CRO } & \multicolumn{5}{|c|}{ OHIP-EDENT-SRB } \\
\hline & Mean & SD & $\begin{array}{l}\text { Corrected } \\
\text { item-Total } \\
\text { correlation }\end{array}$ & $\begin{array}{l}\text { Cronbach's } \\
\text { alpha if item } \\
\text { deleted }\end{array}$ & $\begin{array}{l}\text { Factor } \\
\text { loadings }\end{array}$ & Mean & SD & $\begin{array}{l}\text { Corrected } \\
\text { item-Total } \\
\text { correlation }\end{array}$ & $\begin{array}{l}\text { Cronbach's } \\
\text { alpha if item } \\
\text { deleted }\end{array}$ & $\begin{array}{l}\text { Factor } \\
\text { loadings }\end{array}$ \\
\hline Difficulty chewing & 2.60 & 1.24 & 0.57 & 0.92 & 0.56 & 1.17 & 0.65 & 0.50 & 0.84 & 0.75 \\
\hline Food catching & 1.84 & 1.24 & 0.49 & 0.92 & 0.50 & 0.92 & 0.63 & 0.23 & 0.87 & 0.70 \\
\hline Dentures not fitting & 2.43 & 1.46 & 0.48 & 0.92 & 0.60 & 0.55 & 0.64 & 0.28 & 0.87 & 0.52 \\
\hline Painful aching & .99 & 1.12 & 0.45 & 0.92 & 0.69 & 0.44 & 0.58 & 0.37 & 0.86 & 0.63 \\
\hline Uncomfortable to eat & 2.32 & 1.39 & 0.64 & 0.92 & 0.61 & 1.25 & 0.55 & 0.46 & 0.86 & 0.56 \\
\hline Sore spots & 1.67 & 1.22 & 0.56 & 0.92 & 0.68 & 0.64 & 0.57 & 0.24 & 0.87 & 0.40 \\
\hline Uncomfortable dentures & 2.16 & 1.45 & 0.63 & 0.92 & 0.69 & 0.71 & 0.62 & 0.42 & 0.86 & 0.44 \\
\hline Worried & 2.03 & 1.50 & 0.69 & 0.92 & 0.65 & 1.39 & 0.94 & 0.68 & 0.85 & 0.60 \\
\hline Self-conscious & 1.94 & 1.62 & 0.51 & 0.92 & 0.62 & 2.68 & 0.83 & 0.37 & 0.86 & 0.69 \\
\hline Avoid eating & 2.06 & 1.41 & 0.72 & 0.92 & 0.62 & 1.15 & 0.53 & 0.46 & 0.86 & 0.39 \\
\hline Unable to eat & 1.72 & 1.37 & 0.62 & 0.92 & 0.71 & 1.07 & 0.48 & 0.44 & 0.86 & 0.58 \\
\hline Interrupt meals & 1.35 & 1.33 & 0.65 & 0.92 & 0.73 & 0.16 & 0.43 & 0.34 & 0.86 & 0.42 \\
\hline Upset & 1.91 & 1.54 & 0.79 & 0.91 & 0.78 & 1.59 & 0.97 & 0.63 & 0.85 & 0.67 \\
\hline Embarrassed & 1.51 & 1.35 & 0.74 & 0.91 & 0.77 & 1.62 & 1.18 & 0.61 & 0.86 & 0.69 \\
\hline Avoid going out & 0.87 & 1.21 & 0.56 & 0.92 & 0.71 & 0.83 & 1.00 & 0.72 & 0.85 & 0.69 \\
\hline Less tolerant & 0.45 & .84 & 0.57 & 0.92 & 0.71 & 0.03 & 0.21 & 0.21 & 0.87 & 0.66 \\
\hline Irritable with others & 0.58 & .95 & 0.52 & 0.92 & 0.64 & 0.56 & 0.82 & 0.56 & 0.86 & 0.61 \\
\hline Unable to enjoy company & 0.71 & 1.12 & 0.51 & 0.92 & 0.73 & 0.90 & 0.75 & 0.68 & 0.85 & 0.70 \\
\hline Life less satisfying & 1.07 & 1.26 & 0.61 & 0.92 & 0.66 & 1.93 & 1.07 & 0.58 & 0.86 & 0.64 \\
\hline
\end{tabular}

$\mathrm{SD}=$ standard deviation

\subsubsection{Test-retest reliability}

Thirty CD wearers in each country answered the same questions of the OHIP-EDENT twice, without any treatment between the two administrations. The results are presented in Table 4. The ICC values were high in both countries ( 0.99 and 0.97 in Croatia and Serbia respectively).

\subsection{Validity}

\subsubsection{Concurrent validity}

The concurrent validity was confirmed by a significant negative Spearman's correlation coefficient between the OHIP-EDENT summary scores and one question in which participants rated satisfaction with their dentures. In Croatia the coefficient was $-0.71(\mathrm{P}<0.001)$ and in Serbia $-0.74(P<0.001)$.

Table 4. Test-retest reliability measured by intraclass correlation coefficients (ICC) for the OHIP-CRO-EDENT and the OHIP-SRBEDENT); $n=$ number of participants.

\begin{tabular}{lcccr}
\hline Questionnaire & ICC & $\begin{array}{c}95 \% \text { confidence } \\
\text { interval of the ICC }\end{array}$ & $\begin{array}{c}\text { Mean } \\
\text { difference }\end{array}$ & $\begin{array}{c}95 \% \text { confidence interval } \\
\text { of the difference }\end{array}$ \\
\hline $\begin{array}{l}\text { OHIP-EDENT-CRO } \\
\text { Complete denture wearers }(n=30)\end{array}$ & 0.99 & $0.98-0.99$ & -0.37 & $-1.42-0.69$ \\
$\begin{array}{l}\text { OHIP-EDENT-SRB } \\
\text { Complete denture wearers }(n=30)\end{array}$ & 0.97 & $0.93-0.98$ & -1.0 & $-2.01-0.70$ \\
\hline
\end{tabular}

ICC=intraclass correlation coefficient 


\subsubsection{Construct validity}

The KMO measure 0.871 and Bartlett's Test of Sphericity $1,021.58(\mathrm{df}=171, \mathrm{P}<0.001)$ in Croatia and the $\mathrm{KMO}$ measure 0.85 and Bartlett's Test of Sphericity 1,348.96 (df=171, $P<0.001)$ in Serbia demonstrated sufficient values and significant correlations enabling the performance of EFA. All factor loadings of the OHIP-EDENT-SRB questionnaire were $>0.4$ (except one, which was 0.39). All factor loadings of the OHIP-EDENT-CRO were $>0.5$ (Table 3). In both questionnaires, four factors (dimensions or domains) with eigenvalues $>1$ were extracted. Table 5 shows the eigenvalues and percentages of variance of non-rotated and rotated matrices. The OHIP-EDENT-CRO explains $66.65 \%$ and the OHIP-EDENT-SRB $59.35 \%$ of the variance. When fixed to one factor, the OHIP-EDENT CRO explained $42.51 \%$ of variance, while the OHIP-EDENT-SRB explained $30.66 \%$. In non-rotated matrices, most of the items tended to concentrate on the first factor, while the rotated matrix presented more even distribution (Table 5).

Factor loadings after rotation are presented in Table 6.

Table 5. Factors with eigenvalue $>1.0$ before and after varimax rotation (Croatian OHIP-EDENT and Serbian OHIP-EDENT questionnaires).

\begin{tabular}{|c|c|c|c|c|c|c|c|c|}
\hline \multirow[t]{3}{*}{ Factor } & \multicolumn{4}{|c|}{ OHIP-EDENT-CRO } & \multicolumn{4}{|c|}{ OHIP-EDENT-SRB } \\
\hline & \multicolumn{2}{|c|}{ Unrotated } & \multicolumn{2}{|c|}{ Rotated } & \multicolumn{2}{|c|}{ Unrotated } & \multicolumn{2}{|c|}{ Rotated } \\
\hline & Eigenvalue & $\%$ of variance & Eigenvalue & $\%$ of variance & Eigenvalue & $\%$ of variance & Eigenvalue & $\%$ of variance \\
\hline 1 & 8.08 & 42.51 & 3.88 & 20.41 & 5.83 & 30.66 & 4.75 & 24.98 \\
\hline 2 & 2.10 & 11.04 & 3.38 & 17.78 & 2.72 & 14.33 & 3.22 & 16.94 \\
\hline 3 & 1.35 & 7.08 & 3.03 & 15.93 & 1.50 & 7.90 & 1.77 & 9.33 \\
\hline 4 & 1.13 & 5.96 & 2.37 & 12.47 & 1.23 & 6.44 & 1.54 & 8.08 \\
\hline
\end{tabular}

Table 6. Factor loadings after varimax rotation of the OHIP-EDENT-CRO and the OHIP-EDENT-SRB.

\begin{tabular}{|c|c|c|c|c|c|c|c|c|}
\hline \multirow[t]{3}{*}{ Factor } & \multicolumn{4}{|c|}{ OHIP-EDENT-CRO } & \multicolumn{4}{|c|}{ OHIP-EDENT-SRB } \\
\hline & \multicolumn{4}{|c|}{ Component } & \multicolumn{4}{|c|}{ Component } \\
\hline & 1 & 2 & 3 & 4 & 1 & 2 & 3 & 4 \\
\hline Difficulty chewing & 0.13 & 0.61 & 0.41 & & 0.20 & 0.83 & & \\
\hline Food catching & & 0.35 & 0.61 & & & & 0.83 & 0.11 \\
\hline Dentures not fitting & 0.13 & 0.15 & 0.75 & & & 0.52 & 0.47 & -0.15 \\
\hline Painful aching & 0.10 & 0.13 & & 0.81 & & 0.71 & 0.35 & \\
\hline Uncomfortable to eat & & 0.54 & 0.47 & 0.31 & 0.25 & 0.71 & & \\
\hline Sore spots & 0.20 & 0.33 & & 0.72 & & 0.58 & 0.21 & \\
\hline Uncomfortable dentures & 0.16 & 0.28 & 0.76 & 0.13 & 0.19 & 0.44 & 0.45 & \\
\hline Worried & 0.21 & 0.67 & 0.33 & 0.21 & 0.73 & 0.15 & 0.21 & \\
\hline Self-conscious & & 0.72 & & 0.32 & 0.52 & & & 0.64 \\
\hline Avoid eating & 0.28 & 0.50 & 0.47 & 0.27 & 0.41 & 0.38 & 0.11 & -0.12 \\
\hline Unable to eat & 0.23 & & 0.69 & 0.42 & 0.29 & 0.26 & 0.40 & 0.52 \\
\hline
\end{tabular}




\begin{tabular}{|c|c|c|c|c|c|c|c|c|}
\hline \multirow[t]{3}{*}{ Factor } & \multicolumn{4}{|c|}{ OHIP-EDENT-CRO } & \multicolumn{4}{|c|}{ OHIP-EDENT-SRB } \\
\hline & \multicolumn{4}{|c|}{ Component } & \multicolumn{4}{|c|}{ Component } \\
\hline & 1 & 2 & 3 & 4 & 1 & 2 & 3 & 4 \\
\hline Interrupt meals & 0.38 & 0.19 & 0.25 & 0.70 & 0.19 & 0.60 & -0.15 & \\
\hline Upset & 0.41 & 0.70 & 0.30 & 0.19 & 0.80 & & & 0.16 \\
\hline Embarrassed & 0.57 & 0.64 & 0.19 & & 0.81 & & -0.13 & 0.14 \\
\hline Avoid going out & 0.79 & 0.26 & & 0.13 & 0.76 & 0.20 & 0.19 & -0.11 \\
\hline Less tolerant & 0.76 & & 0.26 & 0.26 & 0.22 & 0.18 & & -0.76 \\
\hline Irritable with others & 0.74 & & 0.23 & 0.19 & 0.60 & & 0.40 & -0.29 \\
\hline Unable to enjoy company & 0.84 & 0.16 & & & 0.80 & 0.12 & 0.14 & -0.21 \\
\hline Life less satisfying & 0.71 & 0.33 & & 0.21 & 0.77 & 0.10 & -0.13 & 0.16 \\
\hline
\end{tabular}

\subsection{Responsiveness}

Responsiveness of the Croatian and Serbian versions of the 19-item OHIP was tested in CD wearers before and after dental implant placement in the mandible. The results are presented in Figure 2. Significant improvement of OHRQoL was achieved in both countries, as expected $(\mathrm{t}=20.9$ in Croatia; $\mathrm{t}=5.05$ in Serbia; $\mathrm{p}<0.001)$. The standardised effect size was high for both countries. However, it was higher in Croatia (3.9 in Croatia, 1.53 in Serbia).

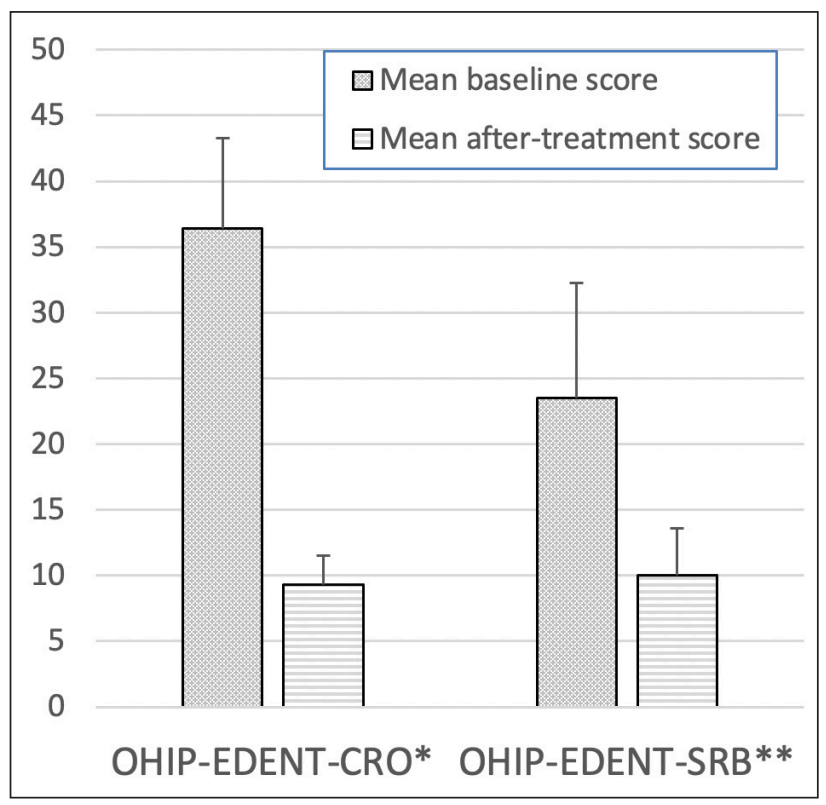

${ }^{*}$ Croatian participants $(n=23)$ received four mini dental implants; ** Serbian participants $(\mathrm{n}=21)$ received two standard-sized implants

Figure 2. Mean baseline and after-treatment scores of the Croatian and Serbian 19-item Oral Health Impact Profiles (before and after implant-supported overdenture treatment in the mandible).

\section{DISCUSSION}

Each questionnaire needs to be validated before it can be used in different cultures. This is due to differences in language, education, amenities, culture, social or economic factors, which are especially important in a disease-specific population (30-33). The need existed in Croatia and Serbia for a disease-specific questionnaire for edentulous subjects. Cross-cultural adaptation of the original OHIP-EDENT instrument was therefore performed (10). Both versions used the original five-point Likert scale instead of the three-point scale of the Brazilian questionnaires $(20,24,37)$. Schools in Croatia and Serbia use a five-point scale, so the participants have already become accustomed to it. The higher summary score obtained among Croatian participants was attributed to the longer period of being edentulous and consequent alveolar ridge atrophy, especially in the mandible, which resulted in reduced denture stability (34-36).

Cronbach's coefficient alpha for internal consistency was calculated to compare the results with other studies. It was higher in Croatia than in Serbia. It was higher than in the Portuguese $(20,24,37)$, Japanese (18) and Nepalese OHIP-EDENT questionnaires (38). However, it was lower than in the Chinese version (19). Cronbach's alpha coefficient in Serbia was similar to the Portuguese $(20,24,37)$ and Japanese (18) versions. The differences between counties can be explained by differences in sampling strategy, duration of edentulism and cultural environments. However, both alpha coefficients were $>0.7$. When the alpha coefficient is close to one, redundant questions may exist. This was not found in this study. Cronbach's alpha coefficient was not calculated for each of the originally proposed seven domains. A recent study on the dimensionality of the 49-item OHIP recommended that one summary score should be used in research using the shortened OHIP versions due to high correlations between factors and the small number of indicators for 
some dimensions (16). As Cronbach's alpha coefficient has recently been criticised (39), another measure for internal consistency, i.e. Guttman's Split-Half coefficient, was also calculated in this study. This revealed that the internal consistency of both questionnaires was good.

The test-retest reliability was also calculated for the summary scores. It was considered that a 15-day period between the two administrations of the questionnaire would be long enough for the participants not to remember the questions, but short enough to prevent changes to oral health. The high ICC values confirmed satisfactory test-retest reliability for the both instruments.

As already mentioned, an EFA was conducted for the purposes of a pilot analysis of the latent structure of the OHIP-EDENT questionnaire. The KMO measure, together with the significance of the Bartlett's Test of Sphericity, confirmed that the data was appropriate for the EFA. All items had adequate loadings, indicating a strong relationship with their factors. The EFA extracted four factors (dimensions) from both questionnaires, similar to the Brazilian study by Souza et al. (24). Another study from Brazil extracted and confirmed three factors: "Physical Impact", "Psychological Impact" and "Social Impact" (36). Five factors were found in the Chinese and Nepalese versions $(18,33)$. The four factors extracted in this study could not be interpreted in a clear manner. According to the content of the items, the dimensions could be: Function, Pain, Comfort and Psychosocial Impact. Due to a lack of questions related to orofacial aesthetics in the OHIP-EDENT questionnaire, the four extracted factors are not in line with the recent four-dimensional oral health model derived from the OHIP-49 questionnaires (2, 5, 1416, 40-43). The confirmatory factor analysis (CFA) was not performed in this study because a new sample was needed for the CFA in both Croatia and Serbia. It is possible that the deletion of some factors with cross-loadings or the insertion of some additional questions related to orofacial aesthetics would have led to a different pattern of factor loadings and groupings.

In the CFA study on the dimensionality of the OHRQoL using the 49-item OHIP, some items had been omitted because they had no salient loadings on one of the four proposed dimensions (16). Moreover, the study in question recommended that condition-specific versions, such as the OHIP-aesthetic and the OHIP-EDENT questionnaires (which was adapted in the present study), be used with one summary score, supported by the OHIP's strong general factor (16). This was done in the present study. When fixed to one factor, the OHIP-EDENT-CRO explained $42.51 \%$ of the variance (total variance was $66.6 \%$ ), and the OHIP-EDENT-SRB explained $30.66 \%$ of the variance (total variance was $59.34 \%$ ).

The confirmatory factor analysis (CFA) was not performed in this study because a new sample in each country must be collected if an adequate CFA is to be performed. The CFA will be the object of further research to yield a better insight into the dimensionality of the OHIP-EDENT questionnaire and the item groupings. An attempt to adapt the OHIP-EDENT to fit into the newly 4-D concept of the OHRQoL through the addition of some items and the deletion of others may also be studied.

The convergent validity of the OHIP-EDENT-CRO and the OHIP-EDENT-SRB was confirmed by significant negative Spearman's rank correlation coefficients between the summary scores and one question in which participants rated their dentures (which represented a measure of the same construct).

One important characteristic of the questionnaire is its sensitivity to changes elicited by treatment, which has been proved in many studies $(44,45)$. In Croatia and Serbia, $C D$ therapy is covered by health insurance. However, dental implant costs must be paid by the patient. Twoimplant supported overdenture has become a minimum standard of mandibular edentulism therapy (47) and, recently, four mini-implants for edentulous patients with slim mandibular ridges (48). We predicted that dental implants would improve OHRQoL in edentulous patients. The cost of implants in Croatia was covered by a research grant. As expected, both treatments increased OHRQoL and significantly reduced the OHIP-EDENT summary scores. After treatment, the summary scores reached almost equal values in both countries. However, a higher effect size was observed in Croatian participants due to their worse baseline oral health, probably resulting from a longer period of edentulism. The results are in line with other studies $(35,48)$. The Serbian participants had to pay dental implant costs and therefore might have had higher expectations.

Limitations of this study are the inclusion of participants with different edentulism durations and the relatively small sample size (which allowed only a pilot study to be conducted on the dimensionality). Further research should be directed towards performing the CFA on new samples from each country and towards the possible exclusion or inclusion of some new items in the OHIP. EDENT questionnaire (2, 4, 13-15).

\section{CONCLUSION}

The OHIP-EDENT-CRO and the OHIP-EDENT-SRB questionnaires demonstrated satisfactory internal consistency, validity and responsiveness. Further dimensionality will be the subject of future studies.

\section{CONFLICTS OF INTEREST}

The authors declare no conflicts of interest. 


\section{FUNDING}

The study was financed by the Croatian Science Foundation (Grant no 1218) and the Ministry of Education and Science of Serbia.

\section{ETHICAL APPROVAL}

Received from the Schools of Dental Medicine in Zagreb (approval no 05-PA-26-6/2015) and Belgrade (approval no $36 / 18)$.

\section{REFERENCES}

1. Sischo L, Broder HL. Oral health-related quality of life: what, why, how, and future implications. J Dent Res. 2011;90:1264-70. doi: 10.1177/0022034511399918.

2. Sekulic S, Theis-Mahon, Rener-Sitar K. A systematic scoping review of oral health models. Qual Life Res. 2019;28:2651-68. doi: 10.1007/ s11136-019-02206-9.

3. Schierz O, John MT, Reissmann DR, Mehrstedt M, Szentpétery A. Comparison of perceived oral health in patients with temporomandibular disorders and dental anxiety using oral healthrelated quality of life profiles. Qual Life Res. 2008;17:857-66. doi: 10.1007/s11136-008-9360-3.

4. Sekulić S, John MT, Davey C, Rener Sitar K. Association between oral health-related and health-related quality of life. Zdr Varst. 2020;59:6574. doi: 10.2478/sjph-2020-0009.

5. Mittal H, John MT, Sekulić S, Theis-Mahon N, Rener-Sitar K. Patientreported outcome measures for adult dental patients: a systematic review. J Evid Based Dent Pract. 2019;19:53-70. doi: 10.1016/j. jebdp.2018.10.005.

6. Jokovic A, Locker D, Stephens M, Kenny D, Tompson B, Guyatt G. Validity and reliability of a questionnaire for measuring child oralhealth-related quality of life. J Dent Res. 2002;81:459-63. doi: 10.1177/154405910208100705.

7. Atchison KA, Dolan TA. Development of the geriatric oral health assessment index. J Dent Educ. 1990;54:680-87.

8. Ohrbach R, Larsson P, List T. The jaw functional limitation scale: development, reliability, and validity of 8 -item and 20 -item versions. J Orofac Pain. 2008;22:219-30.

9. Segù M, Collesano V, Lobbia S, Rezzani C. Cross-cultural validation of a short form of the Oral Health Impact Profile for temporomandibular disorders. Community Dent Oral Epidemiol. 2005;33:125-30. doi: 10.1111/j.1600-0528.2005.00215.x.

10. Allen F, Locker D. A modified short version of the Oral Health Impact Profile for assessing health-related quality of life in edentulous adults. Int J Prosthodont. 2002;15:446-50.

11. Larsson P, John MT, Nilner K, Bondemark L, List T. Development of an Orofacial Esthetic Scale in prosthodontic patients. Int J Prosthodont. 2010;23:249-56.

12. Peršić S, Palac A, Bunjevac T, Celebic A. Development of a new chewing function questionnaire for assessment of a self-perceived chewing function. Community Dent Oral Epidemiol. 2013;41:565-73. doi: 10.1111/cdoe.12048.

13. Slade GD, Spencer AJ. Development and evaluation of the Oral Health Impact Profile. Community Dent Health. 1994;11:3-11.

14. John MT, Reißmann DR, Feuerstahler L, Waller N, Baba K, Larsson P, et. al. Factor analyses of the Oral Health Impact Profile - overview and studied population. J Prosthodont Res. 2014;58:26-34. doi: 10.1016/j. jpor.2013.11.002.
15. John MT, Reissmann DR, Feuerstahler L, Waller N, Baba K, Larsson P et. al. Exploratory factor analysis of the Oral Health Impact Profile. J Oral Rehabil. 2014;41:635-43. doi: 10.1111/joor.12192.

16. John MT, Feuerstahler L, Waller N, Baba K, Larsson P, Celebic A. et al. Confirmatory factor analysis of the Oral Health Impact Profile. J Oral Rehabil. 2014;41:644-52. doi: 10.1111/joor.12191.

17. Slade GD. Derivation and validation of a short-form oral health impact profile. Community Dent Oral Epidemiol. 1997;25:284-90. doi: 10.1111/ j.1600-0528.1997.tb00941.x.

18. Sato $Y$, Kaiba $Y$, Yamaga E, Minakuchi S. Reliability and validity of a Japanese version of the Oral Health Impact Profile for edentulous subjects. Gerodontology. 2012;29:e1033-37. doi: 10.1111/j.17412358.2011.00606.x.

19. He SL, Wang JH. Reliability and validity of a Chinese version of the Oral Health Impact Profile for edentulous subjects. Qual Life Res. 2015;24:1011-16. doi: 10.1007/s11136-014-0822-5.

20. Souza RF, Patrocínio L, Pero AC, Marra J, Compagnoni MA. Reliability and validation of a Brazilian version of the Oral Health Impact Profile for assessing edentulous subjects. J Oral Rehabil. 2007;34:821-26. doi: 10.1111/j.1365-2842.2007.01749.x.

21. Petricevic N, Celebic, A, Papic M, Rener-Sitar K. The Croatian version of the Oral Health Impact Profile Questionnaire. Coll Antropol. 2009;33:841-47.

22. Rener-Sitar K, Petricevic N, Celebic A, Marion L. Psychometric properties of Croatian and Slovenian short form of oral health impact profile questionnaires. Croat Med J. 2008;49:536-44. doi: 10.3325/ cmj.2008.4.536.

23. Stancić I, Sojić LT, Jelenković A. Adaptation of Oral Health Impact Profile (OHIP-14) index for measuring impact of oral health on quality of life in elderly to Serbian language. Vojnosanit Pregl. 2009;66:51155. doi: 10.2298/vsp0907511s.

24. Souza RF, Leles CR, Guyatt GH, Pontes CB, Della Vecchia MP, Neves FD. Exploratory factor analysis of the Brazilian OHIP for edentulous subjects. J Oral Rehabil. 2010;37:202-8. doi: 10.1111/j.13652842.2009.02043.x.

25. Waller N, John MT, Feuerstahler L, Baba K, Larsson P, Peršić S, et. al. A 7-day recall period for a clinical application of the oral health impact profile questionnaire. Clin Oral Investig. 2016;20:91-99. doi: 10.1007/ s00784-015-1484-6.

26. Guillemin F, Bombardier C, Beaton D. Cross-cultural adaptation of health-related quality of life measures: literature review and proposed guidelines. J Clin Epidemiol. 1993;46:1417-32. doi: 10.1016/08954356(93)90142-n.

27. Fabrigar R, Wegener DT. Exploratory factor analysis. Oxford: Oxford University Press, 2012.

28. Husted JA, Cook RJ, Farewell VT, Gladman DD. Methods for assessing responsiveness: a critical review and recommendations. J Clin Epidemiol. 2000;53:459-68. doi: 10.1016/s0895-4356(99)00206-1.

29. Allen PF, McMillan AS, Locker D. An assessment of sensitivity to change of the Oral Health Impact Profile in a clinical trial. Community Dent Oral Epidemiol. 2001;29:175-82. doi: 10.1034/j.1600-0528.2001.290303.x.

30. Stern B, Socan G, Rener-Sitar K, Kukec A, Zaletel-Kragelj L. Validation of the Slovenian version of Short Sense of Coherence Questionnaire (SOC-13) in multiple sclerosis patients. Zdr Varst. 2019;58(1):31-9. doi: 10.2478/sjph-2019-0004.

31. Rener-Sitar K, John MT, Pusalavidyasagar SS, Bandyopadhyay D, Schiffman EL. Sleep quality in temporomandibular disorder cases. Sleep Med. 2016;25:105-12. doi: 10.1016/j.sleep.2016.06.031.

32. Dolenc E, Rotar-Pavlič D. Frailty assessment scales for the elderly and their application in primary care: a systematic literature review. Zdr Varst. 2019;58(2):91-100. doi: 10.2478/sjph-2019-0012.

33. Slavkovic S, Golubovic S, Vojnovic M, Nadj C. Influence of cognitive and motor abilities on the level of current functioning in people with multiple sclerosis. Zdr Varst. 2019;58(2):54-61. doi: 10.2478/sjph2019-0007. 
34. Kovačić I, Čelebić A, Zlatarić DK, Petričević N, Buković D, Bitanga P, et. al. Decreasing of residual alveolar ridge height in complete denture wearers: a five year follow up study. Coll Antropol. 2010;34:1051-6.

35. Kovačić I, Peršić S, Kranjčić J, Čelebić A. A cohort study on short miniimplants for mandibular overdentures compared to those of standard length. Clin Oral Implants Res. 2020;31:121-32. doi: 10.1111/clr.13542.

36. Kovačić I, Peršić S, Kranjčić J, Lešić N, Čelebić A. Rehabilitation of an extremely resorbed edentulous mandible by short and narrow dental implants. Case Rep Dent. 2018:7597851. doi: 10.1155/2018/7597851.

37. Possebon APDR, Faot F, Machado RMM, Nascimento GG, Leite FRM. Exploratory and confirmatory factorial analysis of the OHIP-Edent instrument. Braz Oral Res. 2018;32:e111. doi: 10.1590/1807-3107bor2018.vol32.0111.

38. Shrestha B, Niraula SR, Parajuli PK, Suwal P, Singh RK. Reliability and validity of a Nepalese version of the oral health impact profile for edentulous subjects. J Prosthodont. 2018;27:416-20. doi: 10.1111/ jopr.12513.

39. Sijtsma K. On the use, the misuse, and the very limited usefulness of Cronbach's Alpha. Psychometrika. 2009;74:107-20. doi: 10.1007/ s11336-008-9101-0.

40. John MT, Rener-Sitar K, Baba K, Čelebić A, Larsson P, Szabo G, et al. Patterns of impaired oral health-related quality of life dimensions. J Oral Rehabil. 2016;43:519-27. doi: 10.1111/joor.12396.

41. John MT, Reissmann DR, Čelebić A, Baba K, Kende D, Larsson P, et al. A Integration of oral health-related quality of life instruments. J Dent. 2016;53:38-43. doi: 10.1016/j.jdent.2016.06.006.

42. Reissmann DR, John MT, Feuerstahler L, Baba K, Szabó G, Čelebić $A$, et al. Longitudinal measurement invariance in prospective oral health-related quality of life assessment. Health Qual Life Outcomes. 2016;14:88. doi: 10.1186/s12955-016-0492-9.

43. John MT, Sekulic S, Bekes K, Al-Harthy MH, Michelotti A, Reissman DR, et al. Why patients visit dentists - a study in all World Health Organization regions. J Evid Based Dent Pract. 2020;20:101459. doi: 10.1016/j.jebdp.2020.101459.

44. Persic S, Celebic A. Influence of different prosthodontic rehabilitation options on oral health-related quality of life, orofacial esthetics and chewing function based on patient-reported outcomes. Qual Life Res. 2015;24:919-26. doi: 10.1007/s11136-014-0817-2.

45. Čelebić A, Peršić S, Kovačić I, Buković D, Lešić N, Rener-Sitar K. Comparison of three prosthodontic treatment modalities for patients with periodontally compromised anterior mandibular teeth: a 2-year follow-up study. Acta Stomatol Croat. 2019;53:4-16. doi: 10.15644/ asc53/1/1.

46. Feine J S, Carlsson GE, Awad MA, Chehade A, Duncan W J, Gizani S, et. al. The McGill consensus statement on overdentures. Mandibular twoimplant overdentures as first choice standard of care for edentulous patients. Gerodontology. 2002;19:3-4.

47. Jung RE Al-Nawas B, Araujo M, Avila-Ortiz G, Barter S, Brodala N, et. al. Group 1 ITI Consensus Report: the influence of implant length and design and medications on clinical and patient-reported outcomes. Clin Oral Implants Res. 2018:29(Suppl 16):69-77. doi: 10.1111/clr.13342.

48. Peršić S, Ćelić R, Vojvodić D, Petričević N, Kranjčić, J, Zlatarić DK, et al. Oral health-related quality of life in different types of mandibular implant overdentures in function longer than 3 years. Int J Prosthodont. 2016;29:28-30. doi: 10.11607/ijp.4457. 